\title{
Temporal patterns in size and condition at settlement in two tropical reef fishes (Pomacentridae: Pomacentrus amboinensis and $P$. nagasakiensis)
}

\author{
B. A. Kerrigan* \\ Department of Marine Biology, James Cook University, Townsville, Queensland 4811, Australia
}

\begin{abstract}
Temporal variability in the size, age, and biochemical composition of newly settled fish of 2 tropical reef species, Pomacentrus amboinensis and P. nagasakiensis, were examined over 3 recruitment seasons in the northern Great Barrier Reef, Australia. Juveniles of both species were more variable in composition (CV: 32.2 to $35.8 \%$ ) than size (CV: 5.1 to $5.3 \%$ ) and age (CV: 7.2 to $8.4 \%$ ) at settlement. Overall, $P$. amboinensis settled over a range of ages from 15 to $23 \mathrm{~d}$, while the larval duration of $P$. nagasakiensis ranged from 16 to $24 \mathrm{~d}$. The biochemical composition of both species varied among lunar recruitment pulses. Strong interannual differences in the composition (principally carbohydrate and protein) of $P$. amboinensis juveniles were detected. This variability in nutritional condition of newly settled fish has important implications for future patterns of post-settlement growth and development. $P$. amboinensis and $P$. nagasakiensis settling during a single lunar recruitment episode (pulse) differed in length, body depth, and weight. On average P. nagasaklensis were $2 \mathrm{~mm}$ longer and $0.03 \mathrm{~g}$ heavier at settlement than $P$. amboinensis. $P$. nagasakiensis attained this larger size at settlement by means of a higher average growth rate during the larval period. Juveniles of both pomacentrid species settling at the same time were very similar in nutritional condition. Fish settling in the first pulse of the recruitment season weighed less and contained less lipid than recruits settling in the following month. This suggests that the effect of processes in the pelagic environment controlling the accumulation of energy reserves in juvenile stages of reef fish are not necessarily species specitic.
\end{abstract}

KEY WORDS: Reef fish Condition - Larval duration S Size - Temporal patterns · Post-settlement survival

\section{INTRODUCTION}

Numerical replenishment has been recognised as an important process influencing adult abundance patterns, by researchers studying both pelagic and demersal fish populations (reviews by Doherty 1991. Fogarty et al. 1991, Heath 1992, Doherty \& Fowler 1994). Research has focused on understanding the factors that influence the dynamics of this early life history stage. Much of this research has been concentrated in the northern hemisphere on species for which commercial fisheries exist (Shelbourne 1957, Lasker 1978, Houde 1987, Suthers et al. 1989, Heath 1992). Com-

•E-mail: brigid kerrigan@jcu.edu.au prehensive, long term, multidisciplinary studies have been conducted to monitor larval abundance patterns in relation to food availability, and physical and chemical oceanographic processes (review by Heath 1992). The ultimate goal of the majority of the research covered in these reviews is the prediction of year class strength from information on the temporal and spatial patterns of larval abundance. Making such predictions of year class strength from the abundance patterns of earlier stages alone, however, has proved difficult.

A number of factors can modify the probability of an individual surviving through the various life history stages. Among these, body size has received considerable attention (Policanksy 1982, Rice et al. 1987. Anderson 1988, Pepin 1989, 1991, Lutvak \& Leggett 1992). One hypothesis is that a larger size at a given 
life history stage confers a survival advantage through reduced predation rates (Rice et al. 1993) and enhanced competitive abilities, hence greater access to food resources (Coates 1980, Metcalfe 1986). In addition, the levels of energy reserves (nutritional condition) in larvae potentially provide a buffer against fluctuations in the pelagic environment such as food availability and temperature. Interestingly, a high proportion of northern hemisphere pelagic and benthic fish larvae have been reported in poor condition in the field (Folkvord \& Hunter 1986, Hånkanson 1989, Canino et al. 1991). This suggests that larvae do exist in the plankton in varying states of nutritional condition. Larvae that are capable of depositing energy reserves rather than directing all available energy into growth and development may be able to mobilise and use these reserves during periods of stress (Driedzic \& Hochach.ka 1978). Therefore, the size and nutritional condition of a fish at any age can have important consequences for subsequent growth, survival, and successful transition to the next life history stage (Canino et al. 1991, Håkanson 1993).

Variability in the condition of fish has long been reported for temperate fishes (Lasker 1978, Buckley \& Lough 1987, Canino et al. 1991, Håkanson 1993); it is only lately that this variability has been recognised in tropical fishes (Margulies 1993, MicCormick \& Molony 1993). Recently, the importance of the condition of fish during specific stages of larval development to their survival, growth and successful transition to the next phase has been demonstrated (Chambers et al. 1988). Because small changes in growth and mortality rates potentially have dramatic affects on the magnitude of recruitment events (Houde 1987, Pepin 1991, Rice et al. 1993), detailing temporal variation in the size and condition of both larvae and recruits will surely enhance our understanding of mechanisms controlling the success of cohorts entering adult reef fish populations.

Due to the predominance of studies on numerical recruitment in tropical reef fish ecology the variability in the condition of these fish at the time of settlement has received very little attention (with the exception of McCormick \& Molony 1993). This variability in condition has either been considered insignificant or any small variability that does exist has no bearing on patterns of survival or growth of newly recruited reef fishes. This paper aims to address the first of these assumptions by determining if any significant temporal patterns in the condition of tropical reef fish exist.

Settlement, which often occurs immediately or soon after metamorphosis, is a crucial time in the life history of reef fishes. Little is known, however, about events that occur during this period and how these events can modify post-settlement survival (McCormick 1994). Studies that have looked at this important time in the life history of fishes (with the exception of Brothers et al. 1983) are based on results obtained from fish settled in aquaria (McCormick \& Molony 1993, McCormick 1994) or from samples collected in the field at some variable time (from days up to months) following settlement (Victor 1982, 1986, Pitcher 1988b, Wellington $\&$ Victor 1992). Fish that settled in the aquaria within 24 to $48 \mathrm{~h}$ after capture are obviously physiologically capable of settling, although these fish may not have necessarily settled if they were in their natural environment (pelagic environment adjacent to the reef). The process of settlement includes both attaining a developmental capability and locating a suitable settlement site. Therefore, although providing a valuable contribution to our understanding of larval fish ecology, the results of previous work potentially bias the variances associated with the parameters that are measured (e.g. age, size, condition).

This study represents the first detailed evaluation of the nutritional condition of tropical reef fish at settlement in the field, in combination with age and size. Fish were collected immediately following 'natural' settlement on the reef during successive recruitment seasons. Specifically the following questions are addressed: Do seasonal patterns in biochemical composition (an indicator of nutritional condition), size, and age exist in juvenile reef fish at settlement? Do congeneric species that settle together show similar patterns in nutritional condition within a settlement pulse? Furthermore, how do easily recorded morphometric measures of condition relate to the more labour intensive biochemical indices? Are these relationships consistent among seasons and between congeneric species?

In addressing these questions this study shows that fish do settle in different states of condition. Furthermore, similarities in the condition of recruits of 2 species settling within the same pulse suggest that processes in the plankton that may determine condition are not species specific.

\section{METHODS}

Sampling protocol. Pomacentrus amboinensis and $P$. nagasakiensis were collected in the morning following settlement, from patch reefs located adjacent to the fringing reefs of Lizard Island $\left(14^{\circ} 40^{\prime} \mathrm{S}\right.$, $145^{\circ} 28^{\prime} \mathrm{E}$ ) in the northern section of the Great Barrier Reef, Australia. P. amboinensis and P. nagasakiensis settle at night in high numbers onto natural coral reef isolates (Pitcher 1988a, Meekan 1992). Once settled, fish are relatively site attached. The 2 congenerics were selected for a comparison of size and condition. of fish at settlement, spanning successive recruitment 
seasons. Small reefs were constructed at 2 locations within each of 2 habitats: lagoon and leeward. Recruits were collected from each of the 4 locations in the first recruitment season; thereafter collections were only made in the 2 leeward reef locations due to logistic constraints. Coral isolates provided settlement sites that could be efficiently cleared daily of all newly settled fishes. Reefs were composed of dead branching coral Pocillopora damicornis $(0.5 \times 0.5 \times$ $0.5 \mathrm{~m}$ ) and positioned on sand 15 to $20 \mathrm{~m}$ from the base of the fringing reef, at a depth of 8 to $10 \mathrm{~m}$. Reefs were cleared daily for $10 \mathrm{~d}$ around the new moon using a fish anaesthetic (quinaldine). By clearing reefs on a daily basis it is possible to collect fish within hours of settlement. This assumes that $P$. amboinensis and $P$. nagasakiensis juveniles settle predominantly at night. This assumption is supported in several independent studies, where repeated dusk and dawn collections have shown that pomacentrids do settle at night (Sweatman 1985, Robertson et al. 1988). Recruitment of pomacentrids to the reef occurs in discrete pulses lasting approximately 3 to $5 \mathrm{~d}$, with either a lunar or semi lunar timing (Meekan et al. 1993). Collections were taken for up to 3 lunar months (November to January) during each recruitment season (1990 to 1993) (Table 1). Fish were kept in aquaria for approximately $2 \mathrm{~h}$ following capture to void their stomachs prior to biochemical analyses. All fish were sacrificed by chilling

Size and condition at settlement. Immediately prior to fixation or freezing, the following morphometric measurements were taken, to describe the variability in size at settlement among samples spanning the 3 recruitment seasons: standard length (SL) to the nearest $0.1 \mathrm{~mm}$, and blotted wet weight to the nearest mg Otoliths were removed for aging. Fish were then stored in liquid nitrogen prior to the analyses of total

Table 1. Pomacentrus amboinensis and P. nagasakiensis. List of samples taken of each species that settled during each lunar pulse over 3 recruitment seasons

\begin{tabular}{|llcc|}
\hline Species & $\begin{array}{l}\text { Lunar } \\
\text { pulse }\end{array}$ & Year & $\begin{array}{c}\text { Recruitinent } \\
\text { season }\end{array}$ \\
\hline P. amboinensis & Nov & 1990 & 1 \\
& Dec & 1990 & 1 \\
& Nov & 1991 & 2 \\
& Dec & 1991 & 2 \\
& Jan & 1992 & 2 \\
& Dec & 1992 & 3 \\
P. nagasakiensis & Jan & 1993 & 3 \\
& Nov & 1991 & 2 \\
& Der & 1992 & 3 \\
& Jan & 1993 & 3 \\
& Nov & 1993 & 4 \\
\hline
\end{tabular}

lipids, carbohydrates, and protein. For biochemical analysis fish were freeze dried to a stable weight to derive water content. Each fish was homogenised in $5 \mathrm{ml}$ of $100 \mathrm{mM}$ sodium chloride $(\mathrm{NaCl})$ solution at 0 to $4^{\circ} \mathrm{C}$. Proteins were measured colourimetrically using the method outlined in Bradford (1976). Total lipids were determined using a chloroform:methanol extraction, detailed in Mann \& Gallagher (1985). Total carbohydrates were extracted using a modification of the method used by Mann \& Gallagher (1985) and outlined in McCormick \& Molony (1992). All analyses were carried out in duplicate, and blanks were run simultaneously. The resulting estimates of the biochemical constituents were expressed as $\mathrm{mg} \mathrm{g}^{-1}$ wet weight.

Age at settlement. Daily rings have been validated in recently settled Pomacentrus amboinensis and $P$. nagasakiensis (formerly $P$. melanochir) by Pitcher (1988a). It is assumed that the rings occurring in otoliths of pre-settlement juveniles of both species are also laid down on a daily basis. Otoliths were examined under immersion oil with transmitted light using a compound microscope at $1000 \times$ magnification, equipped with a polarising filter. Twenty-five to 30 otoliths were examined from each sample (pulse), depending on availability. Increments were counted from the nucleus to the outer -most complete ring. Up to 3 independent counts were made until 2 of the counts were identical; this count was accepted as the post-hatch age of the recruit. The otolith was discarded if no agreement was found after 3 counts. Mean growth rate $\left(\mathrm{mm} \mathrm{d}^{-1}\right)$ during the larval period for each fish was calculated by dividing length (subtracting the average length at hatching) by the age at settlement. Average length at hatching for wild spawned larvae of $P$. amboinensis and P. nagasakiensis is $3.04 \mathrm{~mm}$ total length (TL) and $2.83 \mathrm{~mm}$ TL, respectively (Kerrigan unpubl. data)

Analyses. Multivariate analysis of variance (MANOVA) was used to test for patterns in the composition and size of both Pomacentrus amboinensis and $P$. nagasakiensis at settlement, among pulses spanning the 3 recruitment seasons. The nature of the significant differences found by MANOVA was examined using canonical discriminant analysis (CDA). Vectors of the morphometric and biochemical variables that explained the differences among samples were plotted to aid interpretation of the CDA. No estimates for total lipid were available for $P$. amboinensis from the November 1990 settlement pulse (Table 1), therefore this sample was excluded from all multivariate analyses. Replicate samples within recruitment seasons were not available for $P$. nagasakiensis, therefore analyses have focused on comparing pulses. Analysis of variance (ANOVA) on the morphometric and biochemical variables was used to assess the percentage 
variation explained by the factors pulse and season $(P$ nagasakiensis, analysis factor 'pulse' only) The uneven number of pulses within a season necessitated the use of type IV sums of squares in the analysis of $P$. amboinensis recruits. Due to unequal replication (variable numbers of fish per pulse), type III sums of squares were used in the analysis of $P$. nagasakiensis recruits (SAS 1987). Residual analysis was used to test for the assumptions of ANOVA (Snedecor \& Cochran 1980).

The relationships among morphometric and biochemical measures of condition and age were assessed using Pearsons' correlations, for both species. In assessing the relationships between SL and biochemical indices (water, lipid, carbohydrate and protein) the effect of variable age was accounted for using Pearsons' partial correlations.

The effect of variable age and size at settlement on the levels of lipid carbohydrate and protein in recruits of Pomacentrus amboinensis among settlement pulses was assessed using analysis of covariance (ANCOVA). Only fish where estimates for all constituents were available were used in the analysis. This eliminated the November 1990 sample from the analysis. The assumption of homogeneity of slopes was tested prior to the running of ANCOVA (Snedecor \& Cochran 1980). The analysis was only conducted where the covariates size and age were significantly correlated with the biochemical variables.

\section{RESULTS}

\section{Biochemical composition, size and age at settlement}

\section{Pomacentrus amboinensis}

At settlement, fish ranged in size from 10.3 to $15.1 \mathrm{~mm} \mathrm{SL}$ and weighed between 0.027 and $0.12 \mathrm{~g}$. The composition of recruits at settlement was more variable than their length $(\mathrm{CV} \cdot \mathrm{lipid}=26.8 \%$, protein $=$ $31.5 \%$, carbohydrate $=49.0 \%$, length $=5.1 \% \mathrm{l}$. Biochemical composition varied on average by $3.4-$ to 14.1-fold within a pulse (total lipid $=3.4$-fold, protein $=$ 4.7 -fold, carbohydrate $=14.1$-fold). Despite the magnitude in variability within a pulse the size and composition of Pomacentrus amboinensis at settlement varied significantly between 6 settlement pulses spanning 3 recruitment seasons (Pillai's trace: $F_{(30,1090)}=19.89, \mathrm{p}<$ 0.0001). Canonical discriminant analysis (CDA) was used to display the differences among the 6 pulses (Fig, 1). The majority of the variation among pulses was due to differences in protein, carbohydrate and water content $[84 \%$, Can (canonical variate) 1; Fig. 1] Fish from successive pulses within a recruitment sea-

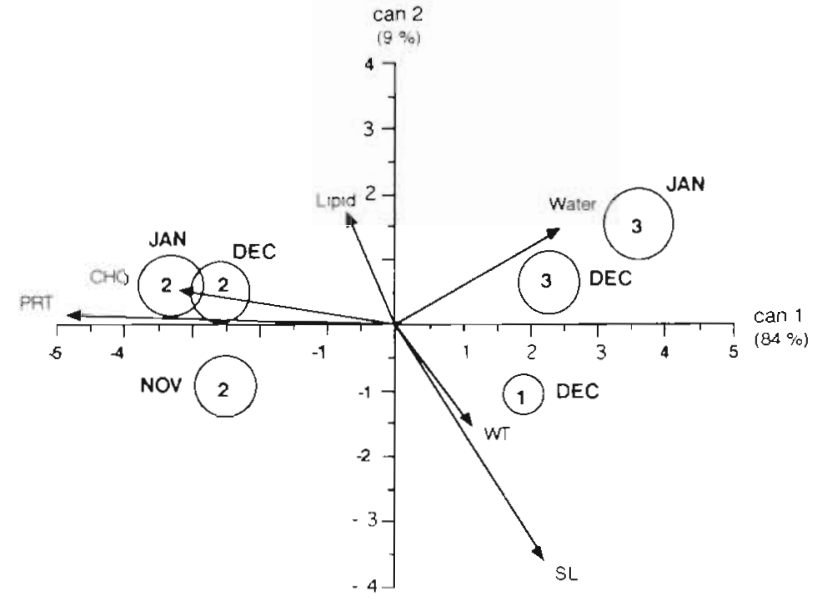

Fig. 1. Pomacentrus amboinensis. Canonical discriminant analysis of size, weight, and biochemical composition at settlement, from 6 recruitment pulses spanning 3 recruitment seasons. November 1990 pulse was cxcluded from analysis (see 'Methods'). Canonical variates (Can) 1 and 2 are displayed. Circles represent $95 \%$ confidence limits derived from the equation $\vee\left(\chi_{2}^{2}, 005 / n\right)$. Numbers within each circle indicate recruitment season. Arrows represent vectors of the variables used in analysis. PRT; protein; CHO: carbohydrate; Lipid: total lipid; WT: wet weight; SL: standard length

son were more similar in composition and size than pulses from different recruitment seasons. Fish settling from November 1991 through to January 1992 (Season 2) contained more protein and carbohydrate and less water than fish settling during December (1992) and January (1993) in the following recruitment season (Season 3) (Fig. 2).

With the exception of lipid content, differences among seasons explained between 13 and $74 \%$ of the variation in biochemical composition of recruits (Table 2). Total lipid content of recruits differed significantly among pulses within a season $\left(F_{\{2,148)}=26.16\right.$, $p<0.0001$ ). Fish settling in November and December 1991 and January 1993 tended to contain more lipids than fish settling in December 1990. January and December 1992 (Fig. 2).

In contrast, seasonal (interannual) differences only accounted for 6.6 to $18 \%$ of the variation in length, weight, growth rate and age at settlement (Table 2). Differences among pulses within a season accounted for 10 to $34 \%$ of the overall variation. Although there were statistically significant differences in mean length and weight at settlement, among pulses within a season (length: $F_{\{2,169)}=12.99, \mathrm{p}<0.0001$; weight: $\left.F_{(2,169\}}=5.42, \mathrm{p}<0.01\right)$ the differences were small, ranging from 11.2 to $12.6 \mathrm{~mm} \mathrm{SL}$ and 0.04 to $0.06 \mathrm{~g}$ (Fig. 3). Overall, Pomacentrus amboinensis at settlement ranged in age from 15 to $23 \mathrm{~d}$. Mean planktonic larval duration of this species ranged from 17.4 to 


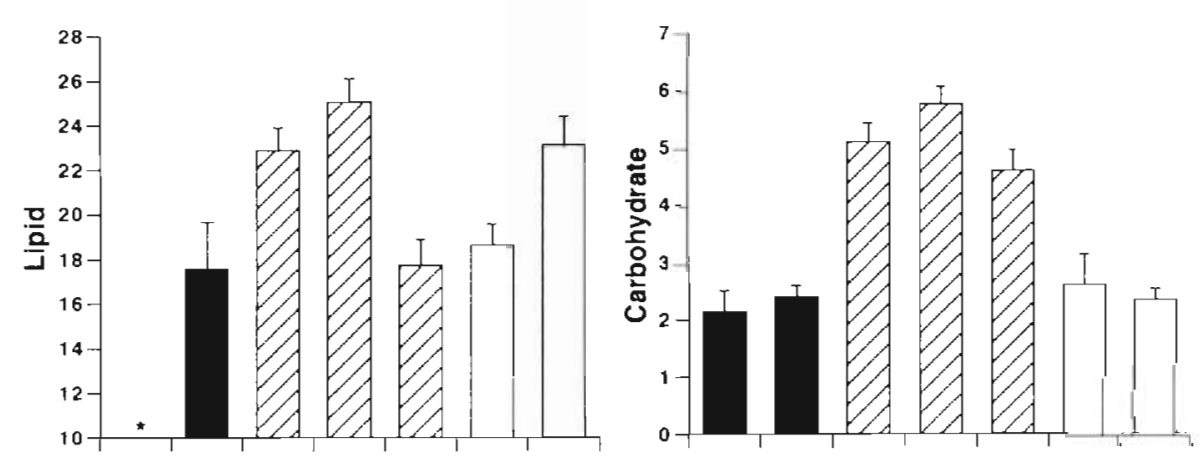

Fig. 2. Pomacentrus amboinensis. Changes in biochemical composition at settlement, from 7 recruitment pulses spanning 3 recruitment seasons. Mean $( \pm \mathrm{SE})$ total lipid, protein, carbohydrate, and water content in $\mathrm{mg} \mathrm{g}^{-1}$. ${ }^{*}$ Data not available
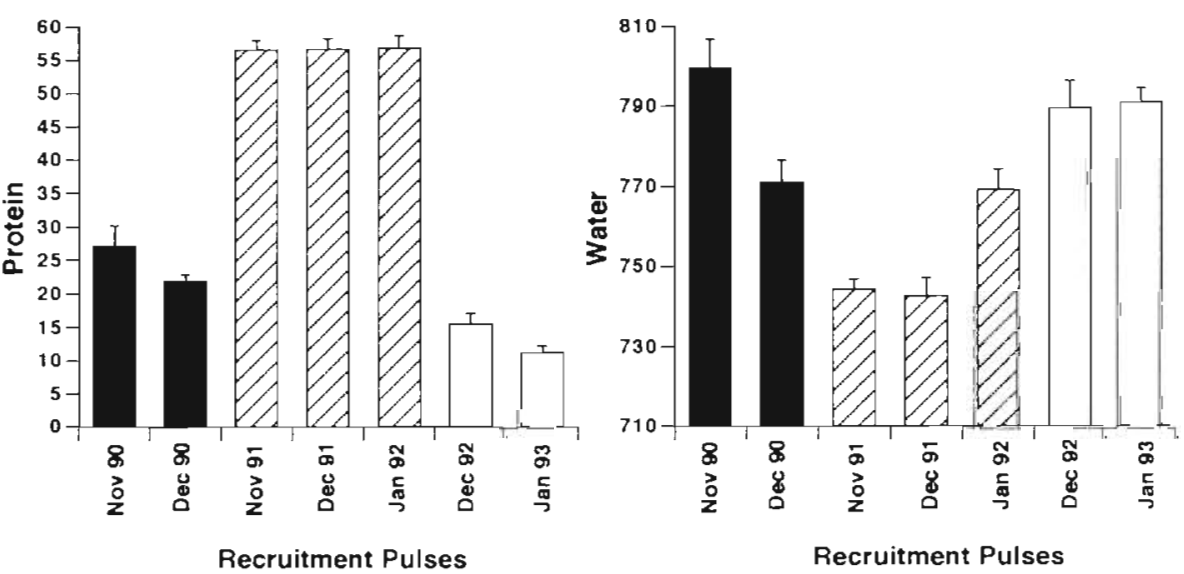

19.8 d (Fig. 4). However, there were no strong seasonal differences in mean larval growth rates. The only significant difference in growth rate was for fish settling in December of the first recruitment season, where the mean larval growth rate was approximately $0.1 \mathrm{~mm} \mathrm{~d}^{-1}$

Table 2. Pomacentrus amboinensis. Summary of ANOVA comparing energy reserves, pre-settlement growth rates, size and age at settlement among pulses spanning 3 recruitment seasons (1990, 1991 and 1992). Percentage varlation (variance components) explained by each factor is given, followed by significance levels. Data are not transformed. Type IV sums of squares used in the analysis (see 'Methods'). S X P: interaction term between season and pulse. ns: non significant at 0.05 level; $" \mathrm{p}<0.05 ; \cdots p<0.01, \cdots p<0.001 . n=225$

\begin{tabular}{|c|c|c|c|c|}
\hline Variable & Season & $\begin{array}{l}\text { Factor } \\
\text { Pulse }\end{array}$ & $\mathrm{S} \times \mathrm{P}$ & Residual \\
\hline Water content & $12.8^{\cdots}$ & $4.2 \cdots$ & $12.9 \cdots$ & 70.1 \\
\hline Lipid & $0 \mathrm{~ns}$ & $2.5 \cdots$ & $39.5 \cdots$ & 58.0 \\
\hline Protein & $74.3^{\cdots}$ & $0 \mathrm{~ns}$ & $1.0 \mathrm{~ns}$ & 24.8 \\
\hline $\mathrm{CHO}$ & $22.3^{\cdots} \cdots$ & $0 \mathrm{~ns}$ & $0 \mathrm{~ns}$ & 76.9 \\
\hline Standard length & $18.1^{\cdots}$ & $2.2^{\circ}$ & $19.5^{\cdots}$ & 60.2 \\
\hline Wot woight & $6.6 \cdots$ & $0.2 n s$ & $9.9^{\cdots}$ & 83.3 \\
\hline Age & $7.8 \cdots$ & $0 \mathrm{~ns}$ & $14.8^{\cdots}$ & 76.9 \\
\hline Growth rate & $16.6^{\cdots}$ & $0.8 \mathrm{~ns}$ & $34.2 \cdots$ & 48.4 \\
\hline
\end{tabular}

greater than fish settling in all other settlement pulses (Fig 4). Overall, individual growth rates varied from 0.35 to $0.67 \mathrm{~mm} \mathrm{~d}^{-1}$.

The length of Pomacentrus amboinensis at settlement was variable, and overall negatively correlated to biochemical composition (lipid, protein, and carbohydrate). This variation in length at settlement could mask seasonal (interannual) differences in the biochemical composition of recruits. Therefore, the observed biochemical components were adjusted for differences in fish length among pulses using ANCOVA. Removing this variability in SL had minimal effect on the differences among pulses in the biochemical composition of recruits. A comparison of the normal (unadjusted) and least square means (adjusted for variable SL) for lipid content indicated that variable length was masking differences among recruits settling during the third recruitment season (December 1992 and January 1993) but these differences were small (Tukey's HSD, and pre-planned comparisons; Fig. 5). However, there were no clear seasonal differences in the lipid content of fish at the time of settlement. This was in contrast to protein content where planned comparisons of means adjusted for length resulted in discrete differences in protein levels among fish settling over the 3 recruitment seasons (Fig. 5). Fish from the second recruitment 

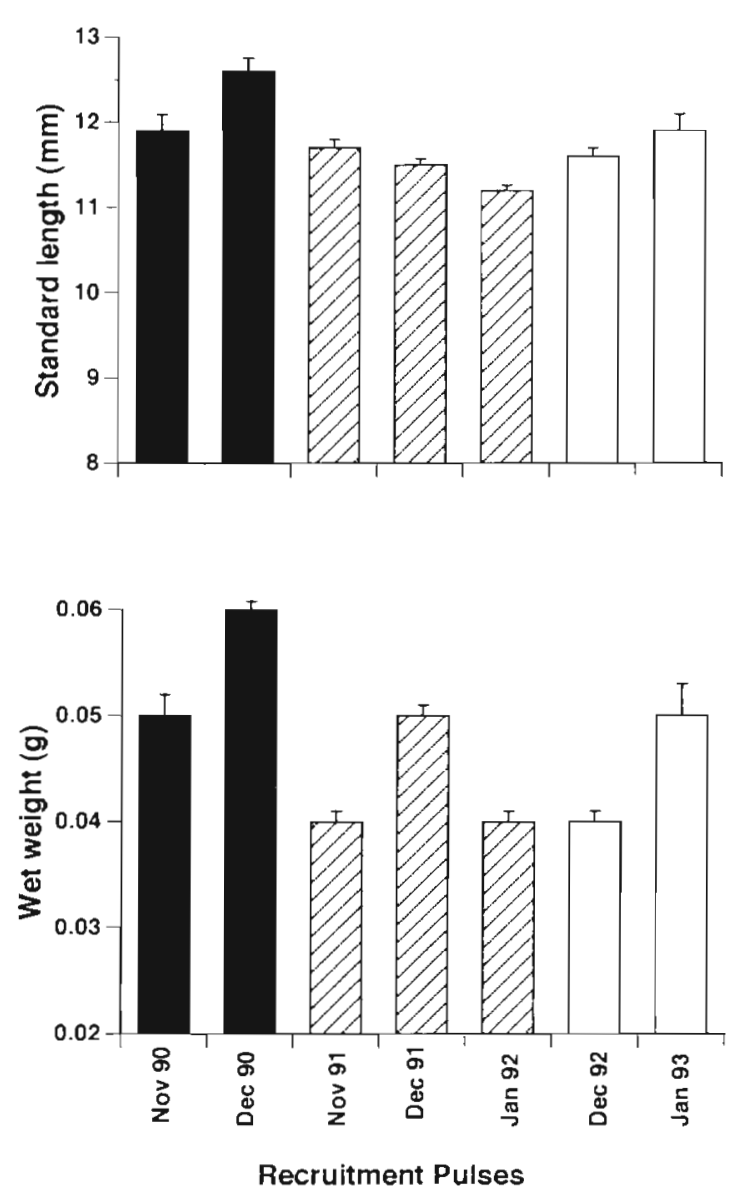

Fig. 3. Pomacentrus amboinensis. Mean $( \pm \mathrm{SE})$ standard length and weight at settlement, from 7 recruitment pulses spanning 3 recruitment seasons

season contained 2.2 times more protein than fish recruiting in the first season and 4 times more than the third season. Patterns in the levels of carbohydrate were not affected by variability in SL.

\section{Pomacentrus nagasakiensis}

Overall, fish ranged in size from 12.0 to $17.8 \mathrm{~mm} \mathrm{SL}$ and 0.032 to $0.2 \mathrm{~g}$ in weight at settlement. Similar to pomacentrus amboinensis, the composition of $P$. nagasakiensis recruits was more variable than their length (CV: lipid $=25.4 \%$, protein $=34.9 \%$, carbohydrate $=36.3 \%$, length $=5.3 \%$ ). Significant differences were detected among the 4 pulses in the size and composition of $P$. nagasakiensis at settlement (Pillai's trace: $\left.F_{\mid 18,495\}}=18.61, \mathrm{p}<0.0001\right)$. The majority of the variation among pulses was due to differences in weight and protein content (76\%, Can 1, Fig. 6). Differences in. SL and water content at settlement explained $13 \%$ of the variation among pulses (Fig 6).
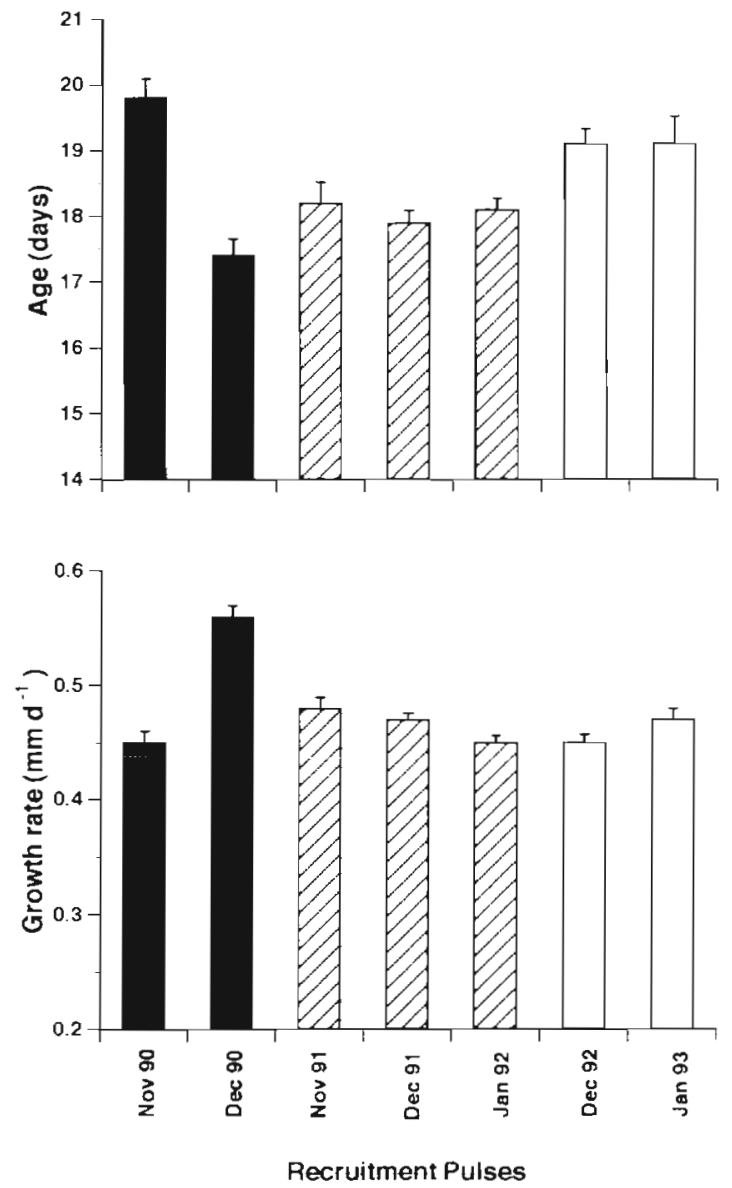

Fig. 4. Pomacentrus amboinensis. Mean ( $\pm \mathrm{SE}$ ) larval growth rate and age at settlement, from 7 recruitment pulses spanning 3 recruitment seasons

Furthermore, the lipid content of recruits varied significantly among pulses $\left(F_{(3,168)}=9.91, p<0.0001\right)$. Fish that settled in November 1991 and January 1993 had on average $22 \%$ more lipid than fish settling during all other pulses (Fig 7). Carbohydrate content and protein levels also differed significantly among pulses (carbohydrate: $F_{13 \mathrm{kie}}=8.36, \mathrm{p}<0.0001 ;$ protein . $\left.F_{(3.168 \mid}=48.08, \mathrm{p}<0.0001\right)$. Fish settling in November 1993 contained $73 \%$ more protein and $29 \%$ more carbohydrate than recruits settling in the November 1991 pulse (Fig. 7).

In contrast, the mean length of recruits settling in different pulses varied by only $0.7 \mathrm{~mm}$ (Fig 8), however. statistical differences were detected due to the relatively small within pulse variance (Fig. 8). A similar result was found for Pomacentrus amboinensis. Interestingly, and in contrast to $P$. amboinensis, the weight of $P$. nagasakiensis varied dramatically among recruitment pulses $\left(F_{(3,158)}=21.5, \mathrm{p}<0.0001\right.$; Fig 8$)$. Fish settling in November 1993 were 1.8 times heavier than recruits settling in the November 1991 pulse. 

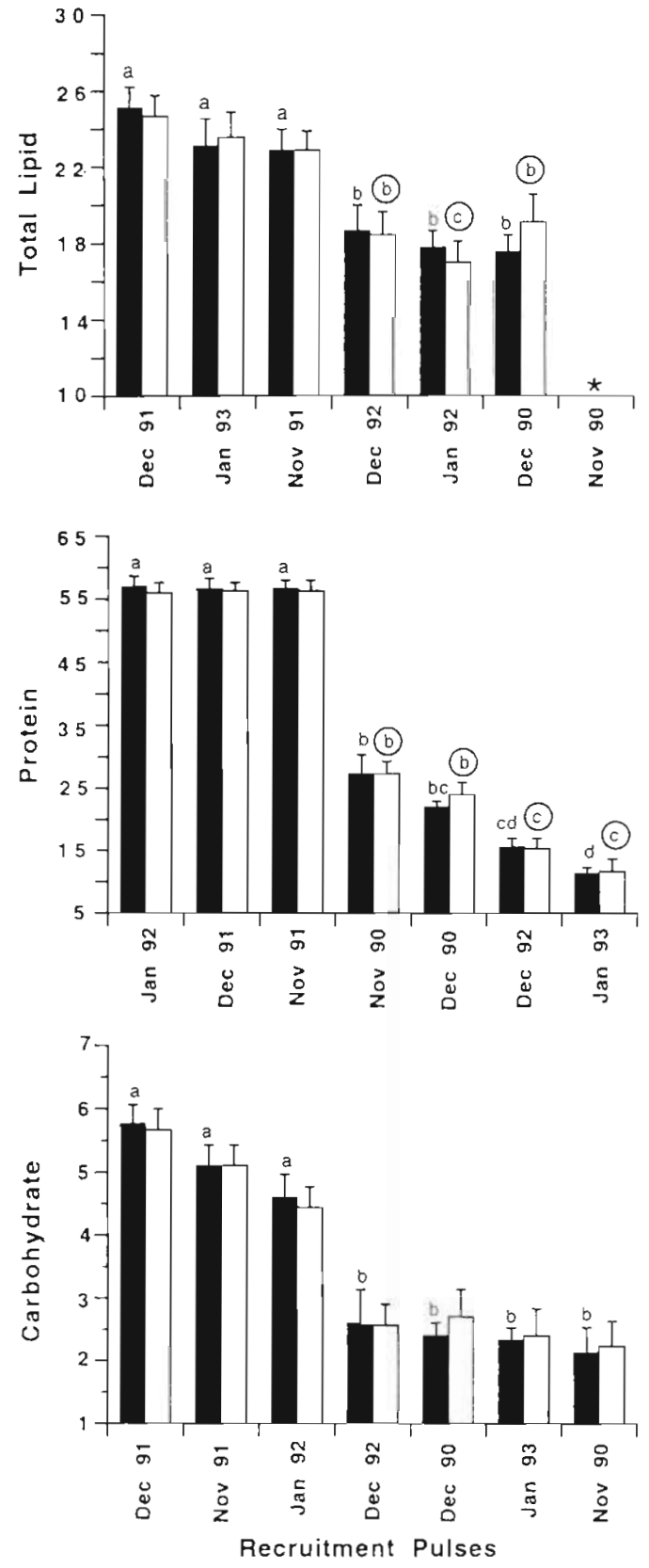

Fig. 5. Pomacentrus amboinensis. Comparison of biochemical composition at settlement, and compositjon adjusted for variable length at settlement (by ANCOVA). Mean ( $\pm \mathrm{SE}$ ) concentration of total lipids, protein, and carbohydrate $\mathrm{mg} \mathrm{g}^{-1}$. Solid bars are unadjusted means. Open bars are least square means adjusted for SL. Means with common letters are not significantly different at the 0.05 level (Tukey's HSD). Letters encased in circles are the result of pre-planned comparisons. Recruitment pulses are arranged in descending order of unadjusted means. *Data not available

Overall, Pomacentrus nagasakiensis recruits varied in age from 16 to $24 \mathrm{~d}$ post-hatch. However, there were no significant differences among pulses in the age of

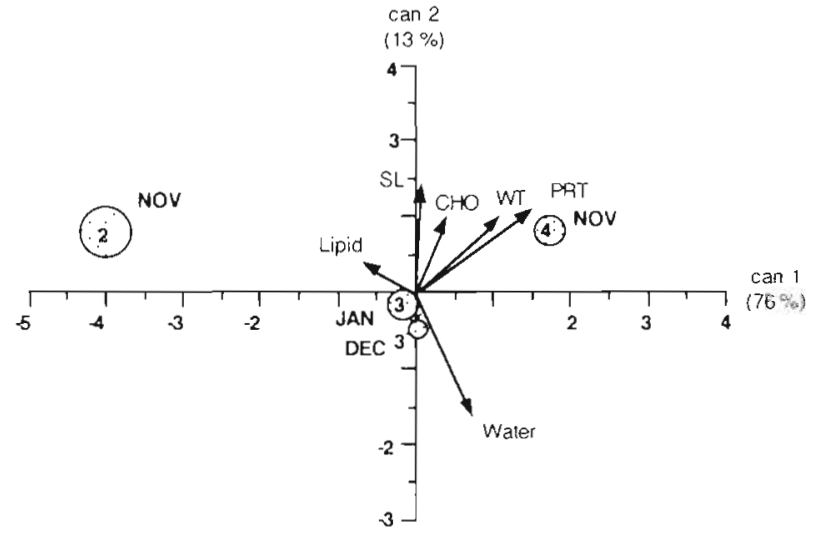

Fig. 6. Pomacentrus nagasakiensis. Canonical discriminant analysis of size, weight, and biochemical composition at settlement, from 4 recruitment pulses spanning 3 recruitment seasons. Canonical variates (Can) 1 and 2 are displayed. Circles represent $95 \%$ confidence limits. Arrows represent vertors of variables used in the analysis. Other symbols as in Fig. 1

fish at settlement $\left(F_{(3,93)}=1.16, \mathrm{p}=0.33\right)$. Mean larval duration ranged from 18.5 to $19 \mathrm{~d}$ (Fig. 9). The mean larval growth rates of fish settling over the 3 recruitment seasons ranged from 0.48 to $0.74 \mathrm{~mm} \mathrm{~d}^{-1}$. Larval growth rates within a pulse varied on average by 1.4 fold. Therefore, some fish at settlement were growing only half as fast as their co-settlers. However, there were no significant differences in growth rates among pulses $\left(F_{i 3,93)}=1.46, p=0.23\right.$; Fig. 9).

\section{Variation between two congeneric species within a recruitment season}

There were significant differences between species and among pulses in the composition and size of fish at settlement (Pillai's trace: $F_{(18,516)}=18.2, p<0.0001$ ). The recruits of the 2 species that settled during the 1992-1993 recruitment season (December and January) were separated due to differences in morphometrics (Can 1 CDA; Fig 10). Interestingly, the biochemical composition (principally lipid content) of fish settling within a pulse was very similar irrespective of species (Can 2; Fig 10). These differences among pulses accounted for $26 \%$ of the overall variation.

Between 46 and $72 \%$ of the variation between species was accounted for by differences in the 2 morphometric variables measured (SL and weight) (Table 3). On average Pomacentrus nagasakiensis were $2 \mathrm{~mm}$ longer and $0.03 \mathrm{~g}$ heavier at settlement (Fig 11). $P$. naqasakiensis achieved this larger size at settlement by a significantly higher mean larval growth rate than $P$. amboinensis $\left(0.58\right.$ vs $\left.0.45 \mathrm{~mm} \mathrm{~d}^{-1}\right)$. There were no significant differences among pulses in the mean 

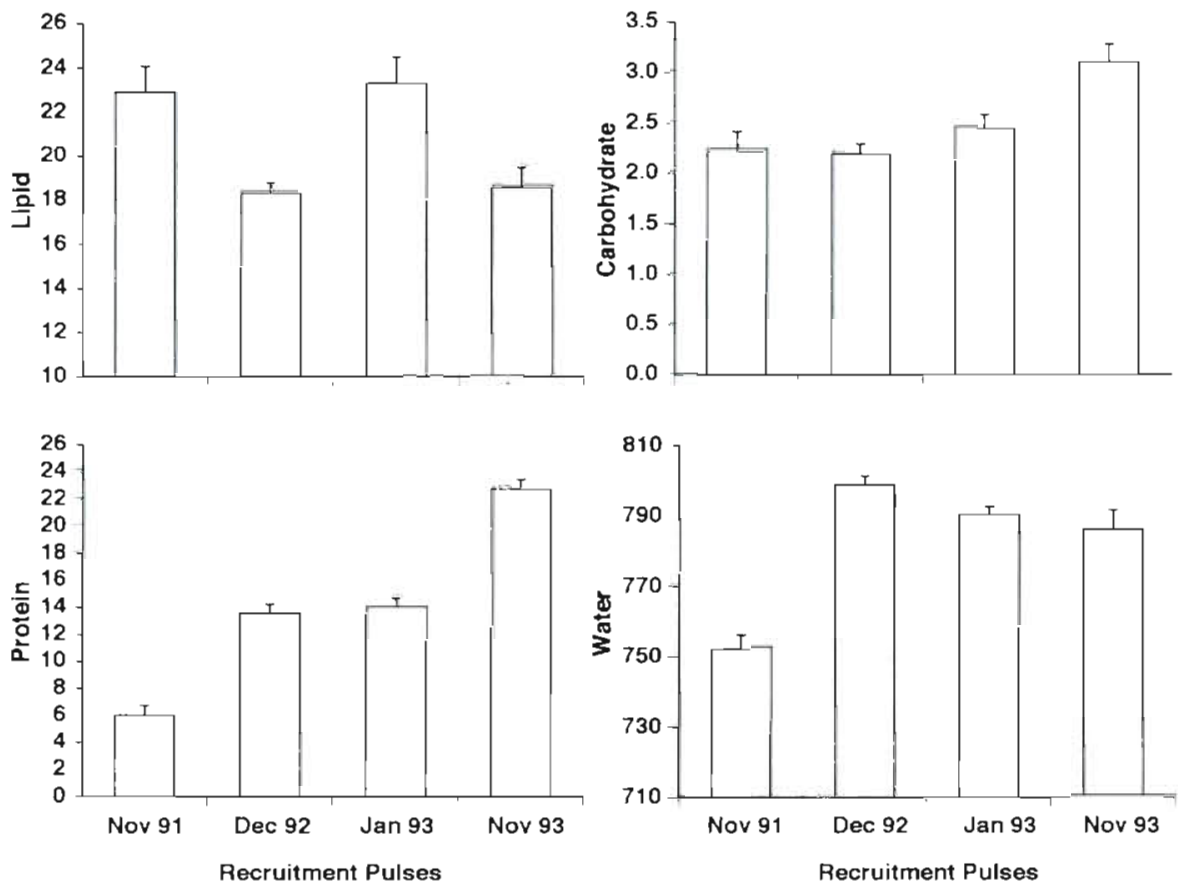

Fig. 7 Pomacentrus nagasakiensis. Changes in biochemical composition at settlement, from 4 recruitment pulses spanning 3 recruitment seasons. Mean $( \pm \mathrm{SE})$ total lipid, protein, carbohydrate, and water content in $\mathrm{mg} \mathrm{g}^{-1}$
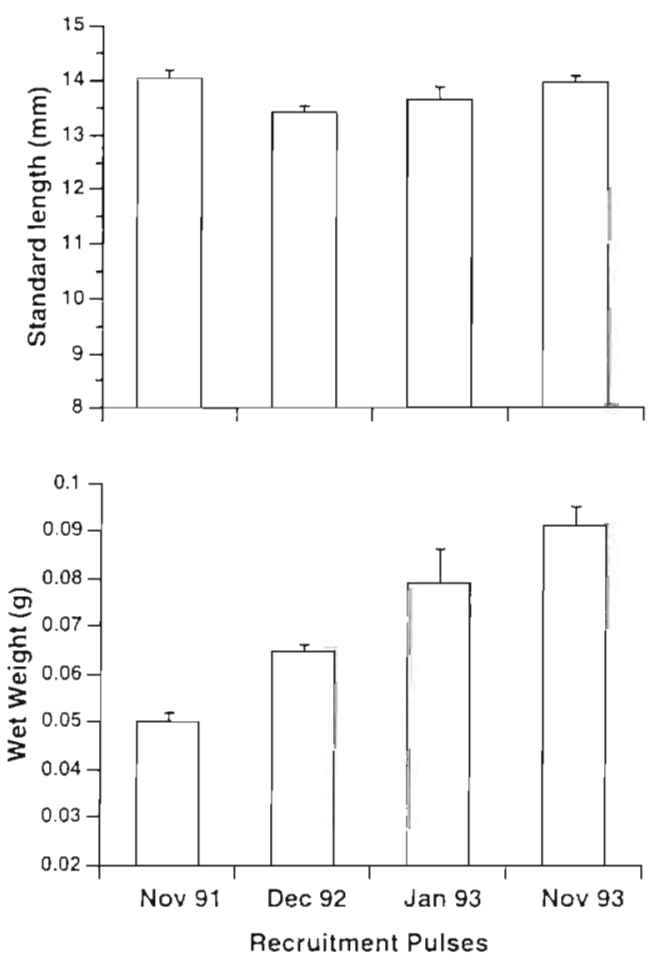

Fig. 8. Pomacentrus nagasakiensis. Mean ( $(\mathrm{SE})$ SL and weight at settlement, from 4 recruitment pulses spanning 3 recruitment seasons
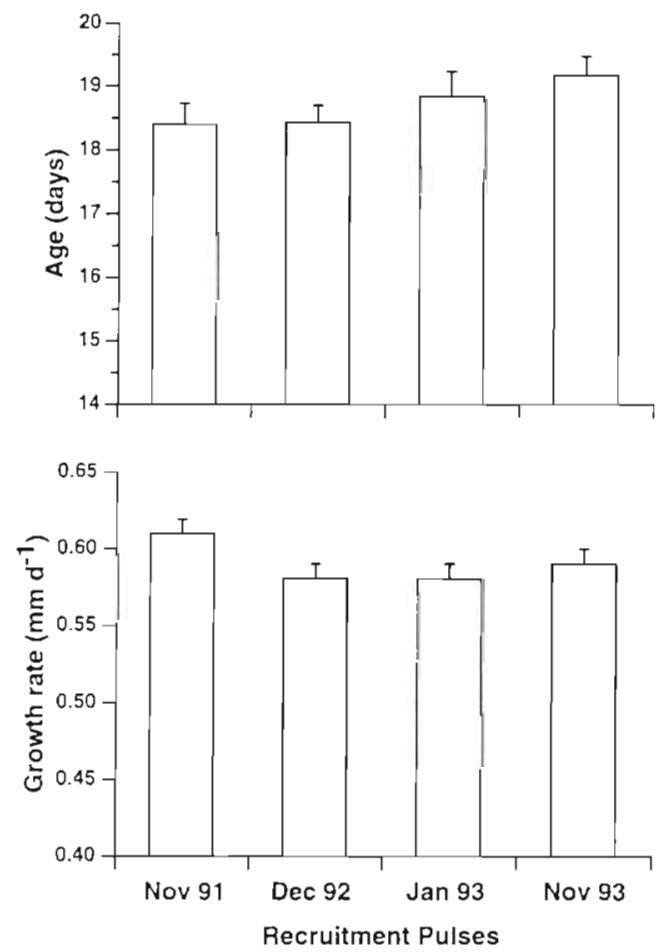

Fig. 9. Pomacentrus nagasakiensis. Mean ( $(\mathrm{SE}$ ) larval growth rate and age at settlement, from 4 recruitment pulses spanning 3 recruitment seasons 


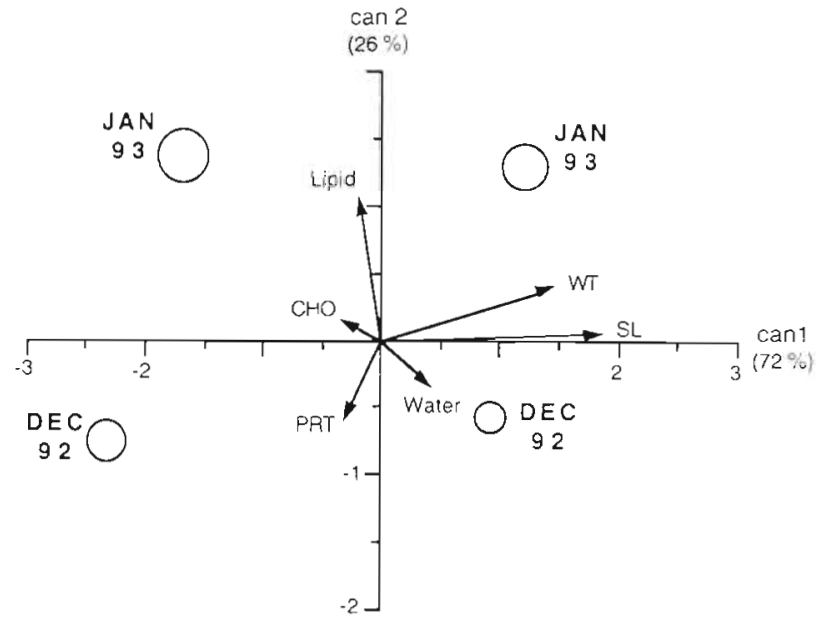

Fig. 10. Pomacentrus amboinensis and P. nagasakiensis. Canonical discriminant analysis comparing size, weight, and biochemical composition at settlement, over 2 successive recruitment pulses. Canonical variates (Can) 1 and 2 are displayed. Circles represent $95 \%$ confidence limits. Shaded circles: P. nagasakiensis, open circles: P. amboinensis. Arrows represent vectors of variables used in analysis. Other symbols as in Fig. 1

larval growth rates of recruits (Table 3, Fig. 11). Both species had similar larval durations $(P$. amboinensis $=$ $19.1 \mathrm{~d}, P$. nagasakiensis $=18.6 \mathrm{~d}$ ) irrespective of when they settled (species: $F_{(1,89)}=1.77, p=0.17$; pulse: $\left.F_{(1.89)}=0.25, \mathrm{p}=0.62\right)$.

Interestingly, recruits of both species settling in the first pulse were smaller and contained significantly less total lipid than recruits settling in the following month (Fig. 11, Table 3). Standard length and weight of recruits of both species increased significantly from the first to the second pulse monitored in the season (Table 3). Pomacentrus nagasakiensis and $P$. amboinensis juveniles settling during this second pulse contained on average about $25 \%$ more lipid than fish settling in the previous recruitment pulse. There were no

Table 3. Pomacentrus amboinensis and P. nagasakiensis. Summary of ANOVA comparing pre-settlement growth rate, size and lipid content at settlement, between 2 pulses within a recruitment season. Percentage variation (variance components) explained by each factor is given, followed by significance level. Data are not transformed. Sp $\times$ P: interaction term between species and pulse. ns: non significant at 0.05 level; $\cdot p<0.05, \cdots p<0.01, \cdots p<0.001 n=179$

\begin{tabular}{|c|c|c|c|c|}
\hline Variable & Species & $\begin{array}{l}\text { Factor } \\
\text { Pulse }\end{array}$ & $S p \times P$ & Residual \\
\hline Standard length & $72.4^{\cdots}$ & $1.4^{\cdots}$ & $0 \mathrm{~ns}$ & 26.2 \\
\hline SAlct weight & $46.8 \cdots$ & $5.1 \cdots$ & 0.115 & 47.7 \\
\hline Growth rate & $65.3 \cdots$ & $0.2 \mathrm{~ns}$ & $0 \mathrm{~ns}$ & 34.5 \\
\hline Lipid & $0 \mathrm{~ns}$ & $21,1 \cdots$ & $0 \mathrm{~ns}$ & 78.9 \\
\hline
\end{tabular}
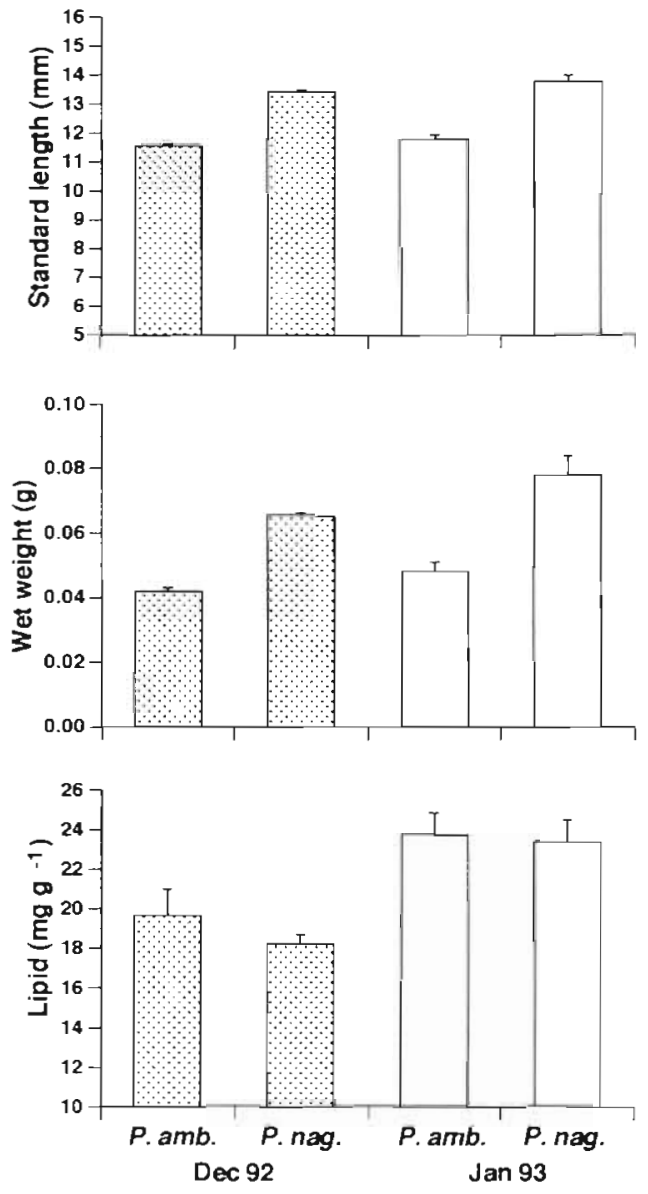

Fig. 11. Pomacentrus ambornensis and P. nagasakiensis. Comparison of size and nutritional condition at settlement, over 2 successive recruitment pulses (December 1992 and January 1993). Mean $( \pm S E) S L$, wet weight, and total lipid content. P. amb.: P. ambionensis; P. nag.: P. nagasakiensis

significant differences between species or pulses in the carbohydrate and water content of recruits (water content: species $F_{(1,175)}=2.60 \mathrm{p}=0.11$, pulses $F_{(1,175)}=0.73$ $\mathrm{p}=0.39$; carbohydrate: species $F_{(1,175)}=1.31, \mathrm{p}=0.25$, pulses $\left.F_{(1,175)}=0.03, p=0.86\right)$. In contrast, protein content was more variable. The significant difference detected among pulses for specific species (species $x$ pulse $\left.F_{(1,175)}=10.3, \mathrm{p}<0.01\right)$ was due to juvenile $P$. amboinensis. Recruits settling during the second pulse contained less protein than fish in the first pulse $\left(10.7 \mathrm{mg} \mathrm{g}^{-1} \pm 0.8 ; 17.9 \mathrm{mg} \mathrm{g}^{-1} \pm 2.0\right)$.

\section{Comparison of measures of condition}

\section{Pomacentrus amboinensis}

There was a positive relationship between length of Pomacentrus amboinensis at settlement and weight; 
Table 4. Pomacentrus amboinensis. Correlations among morphometric variables and biochemical composition at settlement, pooled across all recruitment pulses. Pearson correlation coefficients are given. "Pearson partial correlations partialling out the effect of variable age at settlement. $\mathrm{CHO}$ : total carbohydrate. ns: non significant at 0.05 level; $" p<0.05$, $\cdots p<0.01, \cdots p<0001 . n=153$

\begin{tabular}{|c|c|c|c|c|c|c|c|}
\hline & Age & $\begin{array}{l}\text { Growth } \\
\text { rate }\end{array}$ & $\begin{array}{c}\text { Wet } \\
\text { wt }\end{array}$ & Water & Lipid & Protein & $\mathrm{CHO}$ \\
\hline SL & $\begin{array}{c}0.02 \\
\text { ns }\end{array}$ & $\begin{array}{l}0.71 \\
\cdots\end{array}$ & $\begin{array}{c}0.77^{\circ} \\
\cdots\end{array}$ & $\begin{array}{l}0.12^{d} \\
\text { n.s }\end{array}$ & $-0.16^{\circ}$ & $\begin{array}{c}-0.41^{\mathrm{s}} \\
\ldots\end{array}$ & $\begin{array}{c}-0.33^{\mathrm{a}} \\
\ldots\end{array}$ \\
\hline Age & & $\begin{array}{c}-0.67 \\
\cdots\end{array}$ & $\begin{array}{c}007 \\
\text { ns }\end{array}$ & $\begin{array}{c}0.1 .3 \\
\mathrm{~ns}\end{array}$ & $\begin{array}{c}-0.07 \\
\text { ns }\end{array}$ & $\begin{array}{c}-0.14 \\
\text { ns }\end{array}$ & $\begin{array}{c}-0.09 \\
\text { ns }\end{array}$ \\
\hline Growth & & & $\begin{array}{l}0.49 \\
\cdots\end{array}$ & $\begin{array}{l}0.0 \\
\text { ns }\end{array}$ & $\begin{array}{c}-0.07 \\
\text { ns }\end{array}$ & -0.2 & -019 \\
\hline Wet wt & & & & $\begin{array}{c}0.12 \\
\text { ns }\end{array}$ & -0.18 & $\begin{array}{c}-0.21 \\
\cdots\end{array}$ & -0.19 \\
\hline Water & & & & & $\begin{array}{c}-0.53 \\
\cdots\end{array}$ & $\begin{array}{c}-0.65 \\
\cdots\end{array}$ & $\begin{array}{c}-0.71 \\
\cdots\end{array}$ \\
\hline Lipid & & & & & & $\begin{array}{l}0.29 \\
\cdots\end{array}$ & $\begin{array}{l}0.59 \\
\cdots\end{array}$ \\
\hline Protein & & & & & & & $\begin{array}{l}0.69 \\
\cdots\end{array}$ \\
\hline
\end{tabular}

however, length and age were uncorrelated (Table 4) This implies that the average rate of growth among individual fish is highly variable; however, the proportional increase in weight with length is similar for all fish. Interestingly, fish that weighed more (and were longer) at settlement tended to contain less lipid, protein and carbohydrate per gram of tissue than smaller recruits. As a consequence of length and age being unrelated, there was no relationship between age and biochemical composition of fish.

\section{Pomacentrus nagasakiensis}

In contrast to Pomacentrus amboinensis, length of $P$. nagasakiensis at settlement was positively correlated with larval duration ( $\mathrm{r}=0.41$ ) (Table 5) Similarly, length was positively related to weight. As a result of the positive relationship between length and age, age was positively correlated with weight of $P$. nagasakiensis at settlement. This suggests that growth rates of individual $P$. nagasakiensis in the pelagic phase are less variable than $P$. amboinensis. The relationships between morphological and biochemical measures of condition differed markedly between the 2 species of pomacentrids. In contrast to $P$, amboinensis, the length of $P$. nagasakiensis at settlement was not correlated with biochemical composition (Table 5). Fish that weighed more at settlement contained less lipid (similar to $P$. amboinensis) but interestingly, they contained more protein.
Table 5. Pomacentrus nagasakiensis. Correlations among morphometric variables and biochemical composition at settlement, pooled across all recruitment pulses. Pearson correlation coefficients are given. "Pearson partial correlations partialling out the effect of variable age at settlement. CHO: total carbohydrate. ns: non significant at 0.05 level; $" p<0.05, \cdots p<$ $0.01, \cdots p<0.001 . n=95$

\begin{tabular}{|c|c|c|c|c|c|c|c|}
\hline & Age & $\begin{array}{c}\text { Growth } \\
\text { rate }\end{array}$ & $\begin{array}{l}\text { Wet } \\
\text { wt }\end{array}$ & Water & Lipid & Protein & $\mathrm{CHO}$ \\
\hline SL & $\begin{array}{l}0.41 \\
\cdots\end{array}$ & $\begin{array}{l}0.42 \\
\cdots\end{array}$ & $\begin{array}{l}0.7^{\mathrm{d}} \\
\cdots\end{array}$ & $\begin{array}{c}-0.03^{\mathrm{d}} \\
\text { ns }\end{array}$ & $\begin{array}{c}-0.1^{\mathrm{d}} \\
\mathrm{ns}\end{array}$ & $\begin{array}{l}0.07^{4} \\
\text { ns }\end{array}$ & $\begin{array}{l}0.00^{\circ} \\
\text { ns }\end{array}$ \\
\hline Age & & $\begin{array}{c}-0.65 \\
\cdots\end{array}$ & $\begin{array}{l}0.44 \\
\cdots\end{array}$ & $\begin{array}{c}-0.05 \\
\mathrm{~ns}\end{array}$ & $\begin{array}{c}-0.27 \\
. .\end{array}$ & $\begin{array}{l}0.19 \\
\mathrm{~ns}\end{array}$ & $\begin{array}{l}0.00 \\
\text { ns }\end{array}$ \\
\hline Growth & & & $\begin{array}{c}0.17 \\
\mathrm{~ns}\end{array}$ & $\begin{array}{l}0.01 \\
\text { ns }\end{array}$ & $\begin{array}{l}0.1 \\
\text { ns }\end{array}$ & $\begin{array}{c}-0.06 \\
\text { ns }\end{array}$ & $\begin{array}{c}-0.02 \\
\text { ns }\end{array}$ \\
\hline Wet wt & & & & $\begin{array}{l}0.15 \\
\mathrm{~ns}\end{array}$ & $\begin{array}{c}-0.27 \\
\cdots\end{array}$ & $\begin{array}{l}0.48 \\
\ldots\end{array}$ & $\begin{array}{l}0.14 \\
\text { ns }\end{array}$ \\
\hline Water & & & & & $\begin{array}{c}-0.06 \\
\mathrm{~ns}\end{array}$ & $\begin{array}{l}0.11 \\
\mathrm{~ns}\end{array}$ & $\begin{array}{c}-0.01 \\
\mathrm{~ns}\end{array}$ \\
\hline Lipid. & & & & & & $\begin{array}{c}-0.15 \\
\mathrm{~ns}\end{array}$ & $\begin{array}{l}0.42 \\
\cdots\end{array}$ \\
\hline Protein & & & & & & & $\begin{array}{l}0.41 \\
\cdots\end{array}$ \\
\hline
\end{tabular}

Increases in body weight represents an overall increase in size, and is perhaps more representative of somatic growth than simple linear increases in length. Overall, the weight of recruits of both pomacentrid species at settlement was negatively related to their lipid content (Tables $4 \& 5$ ). This negative relationship suggests that pre-settlement juveniles increased their body weight at the expense of lipid content. Interestingly, this relationship changed over the 3 recruitment seasons. In Pomacentrus amboinensis the weight of fish settling was negatively related to their lipid content in Season 3 only $(r=-0.36, p=0.02)$, while in the first and second season there was no significant correlation ( $\mathrm{r}=0.07, \mathrm{p}=0.77 ; \mathrm{r}=0.05, \mathrm{p}=0.62$; respectively). In contrast, the weight $P$. nagasakiensis at settlement was negatively related to lipid content in the second and third seasons $(r=-0.86, p=0.003 ; r=-0.39, p=$ 0.005 ; respectively) but positively correlated in the fourth season $(r=0.4, p=0.02)$

\section{DISCUSSION}

\section{Variability in nutritional condition}

Spatial and temporal variability in the condition of recent settlers has received very little attention in numerical reef fish recruitment studies. Embodied in the strictly numerical approach to reef fish ecology is the assumption that if there is any variability in condition of recruits, this variability is unrelated to temporal fluctu- 
ations in the magnitude of recruitment events and subsequent persistence of recruits on the reef. However, fish clearly do arrive at the reef in different states of nutritional condition. As shown in this study there were strong interannual differences in the nutritional condition of reef fish at settlement. Furthermore, the biochemical composition (principally lipid content) of recruits from 2 congeneric species settling in the same pulse were very similar. This led to marked differences in the condition of fish among pulses within a recruitment season. A high incidence of fish in paor condition in the field has been reported for northern hemisphere pelagic and benthic species (Folkvord \& Hunter 1986. Hakanson 1989, Canino et al. 1991). Variable planktonic processes leading to patchiness in quality and quantity of food and fluctuations in water temperature have been proposed as the most parsimonious hypotheses to account for this variability in larval condition (Suthers \& Sundby 1993). Anderson (1994) detected significant interannual differences in the condition of pelagic juvenile redfish Sebastes spp. and concluded that condition influenced the range in size over which juveniles metamorphosed. This study represents one of the first detailed investigations of nutritional condition in natural populations of reef fishes. The nutritional status of individual fish at settlement has the potential to modify their post-settlement growth and subsequent survival. Therefore, due to this influence on growth and survival interannual variability in condition potentially has important ramifications for temporal patterns in recruitment success to the adult reef population.

A number of indices have been developed to assess the nutritional status of larvae in the field; these have ranged from morphological (Ehrlich et al. 1976, Powell \& Chester 1985, Margulies 1993, McCormick \& Molony 1993), to histological (O'Connell 1980, Theilacker \& Watanabe 1989, Strüsmann \& Takashima 1990) and biochemical measures (Suthers et al. 1992, Foster et al. 1993, McCormick \& Molony 1993). In this study I compared a series of morphological (length and weight) and biochemical (total lipid, protein, carbohydrate, and water content) measures of condition in individual recruits of 2 congeneric species. The relationships among morphological variables and levels of energy reserves were inconsistent between species and among recruitment seasons. Furthermore, no one morphometric measure was highly correlated with any biochemical measure. In general, the weight of Pomacentrus amboinensis recruits was negatively related to levels of energy reserves. In 2 of the 3 recruitment seasons that were monitored, however, there was no significant relationship between weight and lipid reserves. Similarly tor $P$. nagasakiensis fish weight was only negatively related to lipid content in 2 of the 3 recruitment seasons. This suggests that the relation- ship between body weight and lipid reserves is a complex and highly tenuous one. Detailed experiments investigating the relationship between growth or increase in biomass and lipid reserves are required before further conclusions can be made. Variable relationships between growth and biochemical condition of larvae have also been found in several temperate pelagic species (e.g anchovy Engraulis mordax, Håkanson 1993). In the first comprehensive assessment of condition indices for tropical reef fish, McCormick \& Molony (1993) showed that length at settlement was not a strong predictor of any other measure of quality (biochemical) in the speckled goatfish Upeneus tragula. These results from both temperate and tropical studies indicate that the relationship between any one morphometric index and biochemical measure of condition is complex.

The species specific nature and temporal variability in the relationships among measures of condition shown in this study caution against the comparison of the nutritional status of species using any one measure of condition. This complexity in the relationship between morphometric and biochemical measures of condition stems from a number of sources: (1) the inherent genotypic differences between species in their physiology and growth dynamics; (2) differences in the response of individuals within a species to the complex biotic and abiotic realm of the pelagic environment. Furthermore, relationships among indices and how these reflect changes in the larval environment (e.g food availability) change ontogenetically. Larvae, especially in the early stages of development (i.e. preflexion), are more sensitive to fluctuations in food availability than are juveniles (Powell \& Chester 1985, Margulies 1993, Anderson 1994). It is apparent that in order to derive useful measures of condition it is necessary to collect data on several developmental stages of a number of species, spanning several years

It would be valuable for early life history studies if generalisations could be made about the nutritional condition of larvae (from a range of ecologically similar species) based on the in-depth analyses of a single species. Pomacentrus amboinensis and P. nagasakiensis settling within the same settlement pulse differed significantly in length and weight. These results suggest a degree of coherence between species in the nutritional condition (as measured by lipid levels) of recruits settling within a pulse, as both species showed an increase in lipid levels from the first to the second settlement pulse. The most parsimonious explanation that would account for this trend is that fish settling in the 2 pulses experienced either different temperature (McCormick \& Molony 1995) or feeding regimes in the plankton (variability in the quality and quantity of food). It has been shown for recently settled $P$. 
amboinensis that levels of lipid reserves are closely related to food availability (Kerrigan 1994).

Caution needs to be used, however, in the interpretation of this similarity in condition of the 2 pomacentrid species because data were only available for 2 species settling during 2 pulses within 1 recruitment season. Although these data are insufficient to categorically state that the effect of processes in the pelagic environment controlling the accumulation of energy reserves in juvenile stages act similarly on co-occurring species, they do suggest an interesting trend that warrants further investigation. In contrast, Buckley \& Lough (1987) provided evidence for species specific differences in the relationship between biochemical composition (RNA/DNA ratios) and recent growth of larval haddock Melanogrammus aeglefinus and Atlantic cod Gadus morhua that were collected from the same water mass. It was concluded that the variability between species reflected differences in respective feeding efficiencies. The present study represents one of the few published accounts of species that potentially undergo development in the same water mass displaying similar patterns in nutritional condition through a recruitment season. If this holds for a number of species then the assessment of the nutritional status of reef fish at or immediately prior to settlement may provide insights into growth and development after settlement

Temporal variability in the length of larval life and size at settlement give insights as to how processes in the plankton potentially influence larval growth. There were no strong seasonal differences in mean larval growth rate, larval duration or size at settlement for either species. Overall, there was only a $0.1 \mathrm{~mm} \mathrm{~d}^{-1}$ difference in growth rates and a 1 to $2 \mathrm{~d}$ difference in age in fish among settlement pulses. Significant growth differences among pulses may have been detected if recruits had been collected at the tail ends of the recruitment season where they potentially experience greater variability in environmental factors such as temperature and food availability, which have been shown to influence larval growth (Pepin 1991, McCormick \& Molony 1995). Growth rates documented in this study are conservative estimates, as they represent an integration of growth over the whole larval period and therefore mask any temporal variability. To further complicate the interpretation of mean growth rates, results from laboratory based studies (Milicich \& Choat 1992) suggest that the relationship between otolith growth (increment formation), somatic growth and environmental factors (temperature and food avallability) is complex. However, temporal and spatial differences in larval growth rates are detectable using this method, as shown by McCormick (1994) for the tropical goatfish Upeneus tragula. Age and length of recruits varied significantly among 10 samples spanning 2 recruitment seasons across the northern Great Barrier Reef lagoon (spanning $50 \mathrm{~km}$ ). Essentially, more information is required regarding how events in the pelagic environment affect larval growth and how reliably these changes in growth are recorded in the otolith.

\section{Implications for post-settlement growth and survival}

Variability in the condition recorded in juveniles at settlement may have ramifications for mortality patterns immediately after settlement. Mortality rates are extremely variable during this stage. Estimates ranging from 20 to $75 \%$ have been recorded in a number of tropical reef fish species during the first few weeks post-settlement (Sale \& Ferrell 1988). Predation is indisputably an important source of mortality for newly settled reef fish (Doherty \& Sale 1985, Hixon 1991. Caley 1993). If mortality is biased towards smaller or larger individuals, or depends on an individual's condition, then the initial quality and size of the settlers have an immediate affect on the overall status of the juvenile population. Alternatively, if mortality was random with respect to fish size and condition, the complete spectrum of variability in condition and size would be transferred through to the juvenile reef population. Forrester (1990) found differential losses of smaller individuals in the first few months after settlement of the highly site attached pomacentrid Dascyllus aruanus. In general, experiments investigating the importance of size have obtained mixed results and are principally limited to laboratory experiments on early larval stages of temperate species (review Bailey \& Houde 1989, Litvak \& Leggett 1992). Bertram \& Leggett (1994) found that size of juvenile winter flounder at metamorphosis had no effect on susceptibility to predation. One of the few tests of whether size and nutritional condition affect the probability of an individual succumbing to a predator was conducted by McCormick \& Kerrigan (in press). For the tropical goat fish Upeneus tragula preliminary experiments showed that successful predatory attacks by lizardfish Synodus variegatus (a natural predator of recruits; Sweatman 1984) occurred independently of the size and the condition of recruits. These results suggest that mortality may occur at random with respect to these characteristics, at least for the predator evaluated.

The 2 pomacentrid species in the present study are relatively site attached once settled and form loose social groups. Size hierarchies develop within these social groups that are most distinct during the spawning and recruitment season (author's pers. obs.) Size 
hierarchies play an important role in determining potential growth of individuals (Werner \& Gilliam 1984, Jones 1987). Social control of growth and maturity occurs by dominant individuals modifying the quality and quantity of food eaten by subordinates (Coates 1980, McCarthy et al. 1992, Kerrigan 1994). These social interactions provide a mechanism by which the variability in size and condition of fish at settlement can be propagated through to the post-settlement reef population. Even in the absence of such a mechanism there is still evidence that suggests that variation in early life history traits established in the larval phase percolate through to the early juvenile phase (Chambers et al. 1988). Therefore, the size and condition in which reef fish settle have major implications for survival, growth, time to sexual maturity, and recruitment into the adult population.

The complexity introduced by species specific responses to biotic and abiotic factors makes it extremely difficult to develop accurate models that effectively predict changes in abundance patterns for a given species (Fogarty et al. 1991). To enhance the development of these models there is a need to build on our understanding of larval and juvenile nutritional physiology. There is an immediate need to assess how biotic and abiotic processes in the plankton modulate the observed variability in larval and juvenile growth (Suthers et al. 1989, Håkanson 1993, McCormick \& Molony 1993), swimming abilities (Stobutzki \& Bellwood 1994) and rates of sensory development (McCormick 1993, Miller et al. 1993, Shand 1994). This background information is required before we can truly understand what controls year class strength

The ecological consequences of variation in size and nutritional condition at settlement for post-settlement growth and development needs to be assessed. This study has shown that fish arrive at the reef in very different nutritional states and sizes. Furthermore, similarities in condition between species suggest that planktonic processes that determine the condition and growth of fish act in a manner which is not species specific. The response of larvae to fluctuations in physical (temperature) and biotic (quality and quantity of available food) processes in the plankton would be the most parsimonious explanation for this variability in condition. However, genetically based differences among individuals may also account for some of this variability. The nutritional status of a fish at settlement has the potential to modify that individual's response to extrinsic factors such as habitat structure and intraspecific interactions that influence growth and maturity rates. The prediction of year class strength, therefore, would be arded by research that focuses on the condition of fish around the time of metamorphosis but prior to recruitment to the adult population.
Acknowledgements. This research was supported by grants from the Department of Marine Biology, James Cook University and the Australian Coral Reef Society. Invaluable discussions with Mark MicCormick, Geoff Jones and Howard Choat aided the development of ideas presented in this paper This manuscript has benefited from comments by Mark McCormick, Maria Milicich, Peter Doherty, Geoff Jones, Chris Chambers, Frank Talbot, and 3 anonymous referees. J Mcllwain, V. Hall, M. McCormick, E. Seymore and L. Axe provided enthusiastic assistance in the field. Logistic support was provided by the Department of Marine Biology, James Cook University, and the Lizard Island Research Station. This paper is a contribution from the Lizard Island Research Station, a facility of the Australian Museum

\section{LITERATURE CITED}

Anderson JT (1988) A review of size dependent survival during pre-recruit stages of fishes in relation to recruitment. J Northwest Atl Fish Sci 8:55-66

Anderson JT (1994) Feeding ecology and condition of larval and pelagic juvenile redfish Sebastes spp. Mar Ecol Prog Ser 104:211-226

Bailey KM, Houde ED (1989) Predation on eggs and larvae of marine fishes and the recruitment problem. Adv Mar Biol $25: 1-83$

Bertram DF, Leggett WC (1994) Predation risk during the early life history periods of fishes: separating the effects of size and age. Mar Ecol Prog Ser 109:105-114

Bradford MM (1976) A rapid and sensitive method for the quantitation of microgram quantities of protein utilising the principle of protein-dye binding. Analyt Biochem 72 : $248-254$

Brothers ED, Williams DMCB, Sale PF (1983) Length of larval life in twelve families of fishes at 'One Tree lagoon', Great Barrier Reef, Australia. Mar Biol. 76:319-324

Buckley LJ, Lough RG (1987) Recent growth, biochemical composition, and prey field of larval haddock (Melanogrammus aeglefinus) and Atlantic cod (Gadus morhua) on Georges Bank. Can J Fish Aquat Sci 4 4:14-25

Caley MJ (1993) Predation, recruitment and the dynamics of communities of coral-reef fishes. Mar Biol 117:33-43

Canino MF, Bailey KM, Incze LS (1991) Temporal and geographic differences in feeding and nutritional condition of walleye pollock larvae Theragra chalcogramma in Shelikof Strait, Gulf of Alaska. Mar Ecol Prog Ser 79:27-35

Chambers RC, Leggett WC, Brown JA (1988) Variation in and among carly life history traits of laboratory-reared winter flounder Pseudopleuronectes americanus. Mar Ecol Prog Ser $47: 1-15$

Coates D (1980) Prey-size intake in humbug damselfish, Dascyllus aruanus (Pisces, Pomacentridae) living within social groups. J Anıri Ecol 49:335-340

Doherty P (1991) Spatial and temporal patterns in recruitment. In: Sale PF (ed) The ecology of fishes on coral reefs. Academic Press, London, p 261-292

Doherty P. Fowler A (1994) Demographic consequences of variable recruitment to coral reef fish populations: a congeneric comparison of two damselfishes. Bull Mar Sci 54: $297-313$

Doherty PJ, Sale PF (1985) Predation on juvenule coral reef fishes: an exclusion experiment. Coral Reefs 4:225-234

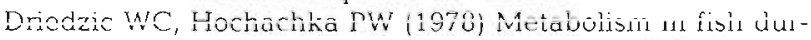
ing exercise. In: Hoar WS, Randall DJ (eds) Fish physiology. Locomotion, Vol. VIl. Academic Press, London, p 503-543 
Ehrlich KF, Blaxter JHS, Pemberton R (1976) Morphological and histological changes during the growth and starvation of herring and plaice larvae. Mar Biol 35:105-1.18

Fogarty MJ, Sissenwine MP, Cohen EB (1991) Recruitment variability and the dynamics of exploited marme populations. TREE 6(8):241-245

Folkvord A. Hunter JR (1986) Size-specific vulnerability of northern anchovy, Engraulis mordax, larvae to predation by fishes. Fish Bull US 84:859-869

Forrester GE (1990) Factors influencing the juvenile demography of a coral reel fish population. Ecology 71. $1666-1681$

Foster AR, Houlihan DF, Hall SJ (1993) Effects of nutritional regime on correlates of growth rate in juvenile Atlantic cod (Gadus morhua): comparison of morphological and biochemical measures. Can J Fish Aquat Sci 50:502-512

Hakkanson JL (1989) Condition of larval anchovy (Engraulis mordax) in the Southern California Bight, as measured through lipid analysis. Mar Biol 102:153-159

Hákanson JL (1993) Nutritional condition and growth rate of anchovy larvae (Engraulis mordax) un the Californian current: two contrasting years. Mar Brol 115:309-316

Heath MR (1992) Field investigations of the early life stages of marine fish. Adv Mar Biol 28:1-174

Hixon MA (1991) Predation as a process structuring coral reef fish communities. In: Sale PF (ed) The ecology of fishes on coral reets. Academic Press, London, p 475-500

Houde ED (1987) Fish early life dynamics and recruitment variability. Am Fish Soc Symp 2:17-29

Jones GP (1987) Competitive interactions among adults and juveniles in a coral reef fish. Ecology 68:1534-1547

Kerrigan BA (1994) Post-settlement growth and body composition in relation to food availability in a juvenile tropical reef fish. Mar Ecol Prog Ser 111:7-15

Lasker R (1978) The relation between oceanographic conditions and larval anchovy food in the California current identification of factors contributing to recruitment failure Rapp PV Réun Cons Int Explor Mer 173:212-230

Litvak MK, Leggett WC (1992) Age and size-selective predation on larval fishes - the bigger-is-better hypothesis revisited. Mar Ecol Prog Ser 81:13-24

Mann K, Gallagher BM (1985) Physiological and biochemical energetics of larvae of Teredo navalis L. and Bankia gouldi (Bartsch) (Bivalvia: Teredinidae). J Exp Mar Biol Ecol 85:211-228

Margulies D (1993) Assessment of the nutritional condition of larval and early juvenile tuna and Spanish mackere (Pisces: Scombridae) in the Panama Bight. Mar Biol 115 $317-330$

McCarthy ID, Carter CG, Houlihan DF (1992) The effect of feeding hierarchy on individual variability in dally feeding of rainbow trout, Onchorhynchus mykiss (Walbaum). J Fish Biol 41:257-263

McCormick MI (1993) Development and change at settlement in the barbel structure of the reel fish, Upeneus tragula (Family: Mullidael. Environ Biol Fish 37:269-282

McCormick MI (1994) Variability in age and size at settlement of the tropical goatfish Upeneus tragula (Mullidae) in the northern Great Barrier Reef lagoon. Mar Ecol Prog Ser 103:1-15

McCormick MI, Kerrigan BA (in press) Predation and its influence on the condition of a newly-settled tropical demersal fish. Mar Freshwat Res $47(3)$

McCormick MI, Molony BW (1992) Effects of feeding history on the growth characteristics of a reef fish at settlement Mar Biol 114:165-173

McCormick MI, Molony BW (1993) Quality of the reef fish
Upeneus tragula (Mullidael at settlement: is size a good indicator of condition? Mar Ecol Prog Ser 98:45-54

McCormick MI, Molony BW (1995) Influence of water temperature during the larval stage on sise, age and body condition of a tropical reef fish at settlement. Mar Ecol Prog Ser 118:59-68

Meekan MG (1992) The influence of pre-and post-settlement processes on the population dynamics of coral reef damselfishes. PhD thesis, Griffith University, Brisbane

Meekan MG, Milicich MJ, Doherty PJ (1993) Larval production drives temporal patterns of larval supply and recruitment of a coral reef damselfish. Mar Ecol Prog Ser 93: $217-225$

Metcalfe NB (1986) Intraspecific variation in competitive ability and food intake in salmonids: consequences for energy budgets and growth rates. J Fish Biol 28:525-531

Milicich MJ, Choat JH (1992) Do otoliths record changes in somatic growth rate? Conflicting evidence from a laboratory and field study of a temperate reef fish, Parika scaber Aust J Mar Freshwat Res 43:1203-1214

Miller TJ, Crowder LB, Rice AJ (1993) Ontogenetic changes in behavioural and histological measures of visual acuity in three species of fish. Environ Biol Fish 37:1-8

O'Connell CP (1980) Percentage of starving northern anchovy, Engraulis mordax, larvae in the sea as estimated by histological methods. Fish Bull 78:475-489

Pepin P (1989) Predation and starvation of larval fish: a numerical experiment of size- and growth-dependent survival. Biol Oceanogr 6:23-44

Pepin P (1991) Effect of temperature and size on development, mortality, and survival rates of the pelagic early life history stages of marine fish. Can J Fish Aquat Sci 48: 503-518

Pitcher CR (1988a) Validation of a technique for reconstructing daily patterns in the recruitment of coral reef damselfish. Coral Reefs $7: 105-111$

Pitcher CR (1988b) Spatial variation in the temporal recruitment of a coral reef damselfish. Proc 6th Int Symp Coral Reef 2:811-816

Policanksy D (1982) Influence of age, size, and temperature on metamorphosis in the starry flounder, Platichthys stellatus. Can J Fish Aquat Sci 39:514-517

Powell AB, Chester AJ (1985) Morphometric indices of nutritional condition and sensitivity to starvation of spot larvae. Trans Am Fish Soc 114:338-347

Rice JA, Crowder LB, Holey ME (1987) Exploration of mechanisms regulating larval survival in Lake Michigan bloater: a recruitment analysis based on characteristics of individual larvae. Trans Am. Fish Soc 116:703-718

Rice JA, Miller TJ, Rose KA, Crowder LB, Marschall EA, Trebitz AS, DeAngelis DL (1993) Growth rate variation and larval survival: interences from an individual-based size-dependent predatıon model. Can J Fish Aquat Sci 50: $133-142$

Robertson DR, Green DG, Victor BC (1988) Temporal coupling of production and recruitment of larvae of a Caribbean reef fish. Ecology 69:370-381

Sale PE, Ferrell DJ (1988) Early survivorship of juvenile coral reef fishes. Coral Reefs 7:117-124

SAS (1987) SAS/statistics users guide for personal computers. Version 6 edn. SAS Institute, Cary, NC

Shand J (1994) Changes in retinal structure during development and settlement of the goatfish Upeneus tragula. Brain Behav Evol 43:51-60

Shelbourne JE (1957) The feeding and condition of plaice larvae in good and bad plankton patches. J Mar Biol Ass UK $36: 539-552$ 
Snedecor GW, Cochran WG (1980) Statistical methods, 7th edn. Lowa State Univ Press, Ames

Stobutzki IC, Bellwood DR (1994) An analysis of the sustained swimming abilities of pre- and post-settlement coral reef fishes. J Exp Mar Biol Ecol 175:275-286

Strussmann CA, Takashima F (1990) Hepatocyte nuclear size and nutritional condition of larval pejerrey, Odontesthes bonariensis (Cuvier et Valenciennes). J Fish Biol 36:59-65

Suthers IM, Frank KT, Campana SE (1989) Spatial comparison of recent growth in postlarval Atlantic cod (Gadus morhua) off southwestern Nova Scotia: inferior growth in a presumed nursery area. Can J Fish Aquat Scj 46 (suppl 1):113-124

Suthers IM, Fraser A, Frank KT (1992) Comparison of lipid, otolith and morphometric condition indices of pelagic juvenile cod Gadus morhua from the Canadian Atlantic. Mar Ecol Prog Ser 84:31-40

Suthers IM, Sundby S (1993) Dispersal and growth of pelagic juvenile Arcto-Norwegian cod (Gadus morhua), inferred from otolith microstructure and water temperature. [CES J Mar Sc1 50:261-270

This article was presented by D. M. Alongi (Senior Editorial Advisor), Townsville, Australia
Sweatman HPA (1984) A tıeld study of the predatory behaviour and feeding rate of a piscivorous coral reef fish, the l.zardfish Synodus englemani. Copeia 1984:187-193

Sweatman HPA (1985) The influence of some species of coral reef fishes on larval recruitment. Ecol Monogr 55: $469-485$

Theilacker GH. Watanabe Y (1989) Midgut cell height defines nutritional status of laboratory raised larval northern anchovy, Engraulis mordax. Fish Bull US 87:457-469

Victor BC (1982) Daily otolith increments and recruitment in two coral-reef wrasses, Thalassoma bifasciatum and Hahchores bivittatus. Mar Biol 71:203-208

Victor BC (1986) Delayed metamorphosis with reduced larval growth in a coral reef fish (Thalassoma bifasciatum). Can $\mathrm{J}$ Fish Aquat Sci 43:1208-1213

Wellington GM, Victor BC (1992) Regional differences in duration of the planktomc larval stage of reef fishes in the eastern Pacific Ocean. Mar Biol 113:491-498

Werner EE, Gilliam JF (1984) The ontogenetic niche and species interactions in size-structured populations. A Rev Ecol Syst $15: 393-425$

Manuscript first received: May 11, 1995

Revised version accepted: November 20, 1995 